\title{
The Social Institution of Economy in the Fiction of Bhabani Bhattacharya
}

\author{
Dr. Kangabam Chanu Lembisana \\ Assistant Professor, JMCE
}

\begin{abstract}
Economy includes the national economy and the economy of an individual as well. Economic institutions are part of the life of the people in a society, and it is the economy of the individual which determines the growth of a society. Economic institutions play a significant part in the progress of an individual and a society as well, and economic institutions are manifold. Feudalism, industrialism, business, property etc. are the major economic institutions in any society. J.L.Gillin and J.P.Gillin contend that "Economic institutions are not of a separate and independent nature. They are part of the culture complex of people" (1). In India, industrial revolution took place in the first half of the twentieth century, and industrialism, as a social institution, affected the common man in the country, and writers were no exception to the influence of the institution. The "zeit-geist" motivated them to exploit economic institutions as fictional materials, and the works of a few writers of the time reflect it.

Bhabani Bhattacharya is renowned for his portrayal of the Indian social scene in his novels, and in So Many Hungers, he has handled the social institution of economy as an appropriate fictional material. It is money and material possessions of a person which determine his / her status in a society and India is no exception to it. In So Many Hungers, Samarendra is the father of the protagonist, Rahoul, and he is a lawyer and a business tycoon as well. He has suffered a great loss in the share market and has been thinking of how to compensate the loss. The time of action in the novel is 1940s when World War II was fought and Indians were struggling for the liberation of the nation from the British yoke. The novelist portrays the sufferings of the people realistically.

One day Samarendra takes his motor car out from the garage to go to his office to attend a meeting of the Board of Directors, and at this juncture, a beggar comes and seeks alms from him. When Samarendra offers him a copper coin, the beggar refuses to accept it. It is a copper coin, and on it, the figure of the goddess of wealth is embossed. It is a time of war and freedom struggle, and therefore, money has lost its value, and people's capacity of buying things has come down. Prices of commodities have shot up, and people undergo extreme hardships, and are unable to buy anything, especially food stuffs. Therefore the beggar refuses to receive the coin from Samarendra, and on the other hand, he wants food only. The coin has lost its monetary value. Samarendra goes away to his office by motor car, and while travelling, a "great idea" flashes across his mind. It is the institution of a company dealing in rice, and the name of the company will be Cheap Rice, Limited.
\end{abstract}

Owing to war and freedom struggle, Indians are experiencing a difficult time and their needs are high. They are unable to buy foodgrains because all the civil supplies are diverted to the frontiers. India is a part of the Allies (it was the case during World War II) and the Japanese forces might attack India at any time. Soldiers should be properly fed and therefore food supplies are sent to these men who are guarding the East coast of India. This is the right time to store grains, thinks Samarendra, and they can be sold when prices are high. This will fetch a huge profit for him. Bhabani Bhattacharya portrays the economy of India which is in doldrums, and the selfishness of the scheming, self-centred business tycoons who desire to exploit the adversity of the innocent masses:

It is strange how great inspiration comes sometimes from matters of no moment. One day as Samarendra was taking his car out from the garage an old beggar whined: "A grain of rice, Father; only a grain." Samarendra offered him a copper, but the white-haired one shook his head with: "What good is that, Father? The goddess is gone from the copper bit, it is an empty shrine. The goddess lives nowhere save in a rice grain."

The goddess lives nowhere save in a rice-grain, mused Samarendra in his car, driving to a Board meeting in Clive Street. And then the great idea flashed upon him. Cheap Rice, Limited. His plans had found an anchor. It was a grand vision. India must mobilize for defence. Bengal would grow into a great military bastion. A million soldiers would be needed to hold the thousand-mile Eastern Front. They would eat their fill. Millions would be engaged in war production, and they, too, would eat their fill. The grain supply from Burma was now lost. If a fraction of Bengal's rice-yield could be cornered-stupendous task! Anyhow, huge stocks could be purchased at the next harvest, laid up, frozen, till demand exceeded supply and the price level rose (one must eat, whatever the price); then the stocks could be slowly released at a huge profit. (2) 
It is an authentic social scene which Bhabani Bhattacharya has portrayed in the novel, and the fictional material, the novelist has employed, pertains to the social institution of economy. Money can do or undo things in a man's life and the scene proves it. Indeed the novelist brings out the hypocrisy of the self-centred rich to the fore, and exposes their evil-mindedness. Samarendra is crooked and from the mind of such a character alone will emanate fiendish thoughts- exploitation of the poor. He is only an instance of the devilishness of the perpetrators of evil who exist in every age and in every country. The appearance of the old beggar in the novel is sudden, and it persists for a fleeting moment only, but it is epiphenomenalist in its impact on Samarendra. The beggar disappears, but the words of the beggar continue to echo within Samarendra, and he resolves to turn a black-marketeer. Samarendra is quick-witted and therefore his resolve is immediate. The writer portrays the "vision" of Samarendra in unequivocal terms. The reader's perception of the scene is clear, for the novelist has employed a right kind of rhetoric on the occasion. The author has employed third person narration which draws the attention of the reader to the fictional material immediately, and he does not ramble in his report of fiction. This method of reporting sustains interest in the reader which persists till the completion of fiction. It is an active report on the fictional situation and the reader develops an artistic illusion of being a partaker of the action in the novel.

It is an irony of situation that a black-marketeer, in the guise of a bigwig in the society, is honoured for his anti-societal activities. Unfortunately the British Government in India confers the title of C.I.E. on Samarendra. The novelist presents the situation:

The first day of the new year had dawned. What a new year for him! His Majesty had conferred the season's Honours as usual, and All India Radio was naming the recipients. K.C.I.E.; . . . C.S.I. Familiar names rushed on. Another big plum for Sir Abalabandhu, as though he had not had enough, Knights. C.I.E. Samarendra gave a start. His name! He had been awarded a C.I.E.!Companion of the Indian Empire. The Empire that had claimed both his sons. (201)Bhabani Bhattacharya's portrayal of the social institution of economy is realistic, and therefore, the reader makes a right perception of the situation in fiction. It is not imperceptible to the reader because what he learns from fiction is what he observes around him in his real life. The novelist has transformed the mundane social institution of economy into artistic fiction dexterously by means of appropriate rhetoric. As seen in the excerpt cited from the novel earlier in this study, here in the second except quoted above, one can see that the novelist's rhetoric is direct, and the reader understands fiction. The irony of situation handled in the second excerpt hastens action further to the resolution at the end of the novel. The reader knows that only cheats and people indulging in criminal deceitfulness alone can make quick money, and the novelist's introduction of the irony of situation confirms it. Bhabani Bhattacharya has employed a language appropriate to the fictional moment and it quickens the rhetorical pace in the novel. There is no verbosity nor can there be seen any ostentatious display of literary devices in both the passages analysed above barring a metaphor appearing in the first passage. But even the metaphor, "an empty shrine," has its significance. It shows the beggar's hunger and dismay, and strengthens the reader's perception of the sufferings of the people. The novelist's right rhetoric, omniscient narration, appropriate use of language and portrayal of human sentiments transform a mundane fictional material based on the social institution of economy into artistically reliable fiction which cannot be seen in the insipid report of a social scientist.

\section{REFERENCES}

[1] Gillin, J.L., and J.P. Gillin. Cultural Sociology( New York: Macmillan, 1948) ,p.374.

[2] Bhattacharya, Bhabani. So Many Hungers (New Delhi: Orient, 1978), pp .39-40.

[3] Ibid.,p.201. 